REFLEKSI HUKUM

Jurnal Ilmu Hukum
p-ISSN 2541-4984 | e-ISSN 2541-5417

Volume 2 Nomor 2, April 2018, Halaman 193 - 206

DOI: https://doi.org/10.24246/jrh.2018.v2.i2.p193-206

Open access at: http://ejournal.uksw.edu/refleksihukum Penerbit: Fakultas Hukum Universitas Kristen Satya Wacana

\title{
PERJANJIAN INTERNASIONAL DALAM HUKUM NASIONAL: PERBANDINGAN PRAKTIK NEGARA INDONESIA, INGGRIS, DAN AFRIKA SELATAN
}

\author{
Ninon Melatyugra \\ Fakultas Hukum Universitas Kristen Satya Wacana \\ Korenpondensi: ninon.melatyugra@staff.uksw.edu \\ Titon Slamet Kurnia \\ Fakultas Hukum Universitas Kristen Satya Wacana \\ Korenpondensi: titonslamet@gmail.com
}

\begin{abstract}
Abstrak
Artikel ini hendak mendiskusikan isu tentang daya keberlakuan perjanjian internasional dalam hukum nasional. Pembahasan atas isu tersebut dilakukan dengan jalan perbandingan hukum (comparative law) praktik negara Indonesia, Inggris, dan Afrika Selatan. Titik tolak substansial dalam melakukan perbandingan hukum tersebut adalah tidak atau kurang memadainya respons terhadap perjanjian internasional menyangkut isu keberlakuan atau aplikabilitasnya di depan forum pengadilan domestik. Isu ini muncul dikarenakan perbedaan pandangan tajam di Indonesia menyangkut mazhab dalam hubungan antara hukum nasional dan internasional. Dengan perbandingan sistem konstitusional di tiga negara tersebut, akan dihasilkan suatu deskripsi tentang sistem penerimaan perjanjian internasional dan suatu preskripsi bagi Indonesia untuk menyelesaikan isu problematik terkait aplikabilitas perjanjian internasional di depan forum pengadilan nasional.
\end{abstract}

Kata kunci: Perjanjian Internasional, Hukum Internasional, Pengadilan Nasional.

\begin{abstract}
This article is aimed to discuss an issue regarding the entry into force of treaties in municipal law. The analysis is undertaken by comparative approach in order to describe the domestic practices in Indonesia, the United Kingdom, and South Africa. A substantial starting point using the comparative law is the inadequate responses to treaties application before the municipal courts. The inadequate responses are indicated by various opinions and schools on seeing the relationship of international law and municipal law. As the main analysis part of this article, the comparison of the constitutional system in those three states will give a description of their acceptance domestic system to treaties and also a prescription for Indonesia to settle its problems regarding the application of treaties before its municipal courts.
\end{abstract}

Keywords: Treaties, International Law, Municipal Courts. 


\section{PENDAHULUAN}

Peningkatan interpenetrasi hukum internasional dan hukum nasional di berbagai aspek mencerminkan hubungan yang semakin kompleks antara negara dengan komunitas internasional. ${ }^{1}$ Aplikabilitas hukum internasional dalam forum pengadilan nasional menjadi isu yang penting dalam menjustifikasi legitimasi praktik penggunaan hukum internasional tersebut. Lazimnya, legitimasi penggunaan hukum internasional dapat dilihat dari konstitusi suatu negara. Mengambil contoh, The Constitution of The Republic of South Africa pada Article 39 memberi otorisasi konstitusional langsung kepada pengadilan nasional untuk menggunakan hukum internasional dan hukum asing dalam hal interpretasi hak asasi manusia. Hal ini memberikan harapan untuk terwujudnya konsistensi dan keseragaman praktik pengadilan nasional dalam mengaplikasikan hukum internasional pada aras domestik.

Hal berbeda dihadapi oleh Indonesia karena Undang-Undang Dasar Negara Republik Indonesia Tahun 1945 (UUD NRI Tahun 1945) tidak mengatur mengenai kedudukan hukum internasional dalam sistem hukum nasional. ${ }^{2}$ Undang-Undang No. 24 Tahun 2004 tentang Perjanjian Internasional pun tidak menjelaskan posisi hukum internasional (dalam hal ini perjanjian internasional) melainkan hanya menjelaskan mekanisme pembuatan dan pengesahan perjanjian internasional. Gap dalam peraturan perundang-undangan di Indonesia menyebabkan keberagaman cara pandang terhadap hukum internasional serta inkonsistensi praktik pengadilan nasional terhadap aplikasi hukum internasional.

Isu ini harus diberikan solusi yang arah preskripsinya adalah memperjelas kedudukan hukum internasional (dalam hal ini perjanjian internasional) guna memberikan kepastian hukum bagi negara yang hendak menjalin hubungan dengan Indonesia, terutama supaya sikap Indonesia (termasuk badan yudisialnya) dapat lebih prediktabel ketika memberlakukan perjanjian internasional di ranah domestiknya. Untuk memper-oleh insight dalam pembahasan isu ini, akan dilakukan analisis perbandingan hukum dengan fokus praktik negara terkait dengan isu kedudukan perjanjian internasional di depan forum nasional. Negara-negara sebagai pembanding adalah Inggris dan Afrika Selatan. Sesuai dengan yang dijanjikan, fokus utama tulisan ini adalah memberikan solusi berupa preskripsi atas isu yang didiskusikan dengan, tentu saja, mengacu pada praktik negara yang dijadikan pembanding.

\section{PEMBAHASAN}

\section{Teori Penerimaan Perjanjian Inter- nasional oleh Negara}

Bagian ini menjelaskan theory of international law before municipal courts

Malcolm N. Shaw, International Law: Sixth Edition (Cambridge University Press 2008) 129-130.

Pasal 11 UUD NRI 1945 hanya mengatur kewenangan presiden dengan kewenangan DPR RI untuk membuat perjanjian dengan negara lain. 
untuk memahami kerangka teoretis sistem penerimaan perjanjian internasional secara umum di suatu negara (dalam konteks tulisan ini adalah pengadilan nasional). Secara tradisional, teori penerimaan perjanjian internasional oleh negara didasarkan pada teori monisme dan teori dualisme.

Teori monisme dikembangkan dari mahzab hukum alam. ${ }^{3}$ Kalangan monist beranggapan bahwa hukum internasional dan hukum nasional merupakan satu kesatuan sistem hukum yang terintegrasi dan tidak dapat dipisahkan. ${ }^{4}$ Teori monisme yang paling kuat mendasarkan primatnya pada supremasi hukum internasional, dengan kata lain, apabila terjadi konflik di antara hukum internasional dan hukum nasional maka hukum internasional yang akan diberlakukan. Namun dalam perkembangannya, teori monisme memiliki varian yang diantaranya berpendapat:

“...without legislation, a treaty may become part of domestic law once it has been concluded in accordance with the constitution and has entered into force for the State". ${ }^{5}$

Hal tersebut menunjukkan bahwa hukum internasional, tanpa legislasi, dapat diberlakukan sepanjang ia sesuai dengan konstitusi suatu negara.
Teknik yang digunakan teori monisme ini adalah teknik inkorporasi di mana negara dapat menerapkan hukum internasional di wilayah hukum nasional tanpa mengubah dasar hukumnya ${ }^{6}$ atau melalui tindakan transformasi ke dalam legislasi nasional. Umumnya, luaran dari teknik inkorporasi ini adalah perjanjian internasional yang bersifat selfexecuting yang dapat diberlakukan secara langsung dalam wilayah hukum nasional. ${ }^{7}$

Berbeda dengan teori monisme, teori dualisme meletakkan hukum internasional terpisah dengan hukum nasional (international law is not ipso facto part of municipal law $\left.{ }^{8}\right)$. Di bawah teori dualisme, konstitusi menegaskan tidak ada status khusus bagi perjanjian internasional, segala hak dan kewajiban yang diciptakan melalui perjanjian internasional tidak memiliki daya keberlakuan di hukum domestik kecuali proses legislasi nasional terpenuhi. ${ }^{9}$ Teori yang kuat muncul di permulaan abad ke-1810 ini memberi supremasi pada hukum nasional berdasarkan kedaulatan negara sehingga hukum internasional tidak dapat memaksa suatu negara patuh terhadapnya ${ }^{11}$.

Teknik yang digunakan teori dualisme adalah teknik transformasi

3 Basak Cali, The Authority of International Law: Obedience, Respect, and Rebuttal (Oxford University Press 2015) 137.

$4 \quad$ Hersch Lauterpacht, International Law: Collected Papers (Cambridge University Press 1970) 216. Baca juga Martin Dixon, Textbook on International Law (Blackstone Press Limited 1993) 69.

$5 \quad$ Anthony Aust, Handbook of International Law (Cambridge University Press 2010), 76.

6 Damos Dumoli Agusman, Treaties Under Indonesian Law: A Comparative Study (Remaja Rosdakarya 2014) 85.

Ibid, 101.

Martin Dixon, Op.Cit. 74.

Anthony Aust, Op.Cit., 75.

John O’Brien, International Law (Cavendish Publishing Ltd London 2001)108.

Ninon Melatyugra, 'Mendorong Sikap Lebih Bersahabat terhadap Hukum Internasional: Penerapan Hukum Internasional oleh Pengadilan Indonesia' (2016) 1 Refleksi Hukum 45, 48. 
dimana penerapan hukum internasional harus diikuti dengan proses legislasi untuk mengubah hukum internasioanl menjadi bagian dari hukum nasional. Dengan demikian, luaran dari teknik transformasi ini adalah treaties yang bersifat non-selfexecuting atau tidak dapat diberlakukan secara langsung sebelum prosedur transformasi dilakukan.

Terlepas dari dominasi teori monisme-dualisme di atas, teori klasik tersebut memiliki beberapa kelemahan. Pertama, teori monisme-dualisme bersifat ex-post yang hanya melihat pada praktik-praktik negara saja. Kedua, teori monisme-dualisme kurang mengandung normative content yang tidak dapat digunakan sebagai argumen di pengadilan. Ketiga, teori monismedualisme tidak mampu menghadapi praktik overlapping terhadap teori itu sendiri di suatu negara. ${ }^{12}$

\section{Praktik Indonesia}

UUD NRI 1945 pada Pasal 11 ayat (1) menyatakan, "Presiden dengan persetujuan Dewan Perwakilan Rakyat menyatakan perang, membuat perdamaian dan perjanjian dengan negara lain". Dalam hal perjanjian internasional tersebut memberi dampak yang luas dan mendasar bagi kehidupan rakyat terkait beban keuangan negara dan/atau mengharuskan perubahan pembentukan UU maka perjanjian internasional tersebut harus dengan persetujuan DPR.13 Ketentuan lebih lanjut mengenai perjanjian internasional diatur dalam UU No. 24 Tahun 2000 tentang Perjanjian Internasional yang mengatur aspek internal dari treaty-making process. Pada Ketentuan Konstitusional yang demikian, UUD NRI 1945 sebenarnya tidak menjelaskan bagaimana posisi hukum internasional dalam hukum nasional. Konstitusi hanya menjelaskan mengenai kewenangan presiden dan hubungannya dengan DPR dalam membuat perjanjian internasional.

Pada isu aplikabilitas perjanjian internasional di depan forum pengadilan nasional, peran hakim menjadi penting untuk diobservasi. Secara konstitusional, pelaku kekuasaan kehakiman di negara Indonesia dipegang oleh Mahkamah Agung (MA) dan Mahkamah Konstitusi (MK). ${ }^{14}$ Dalam menjalankan kekuasaan kehakiman, para hakim MA dan MK wajib menegakkan hukum dan keadilan berdasarkan Pancasila dan UUD NRI 1945. ${ }^{15}$

Namun sayangnya, ketiadaan norma eksplisit dalam UUD NRI 1945 mengenai posisi hukum internasional menciptakan barrier dalam isu aplikabilitas perjanjian internasional di pengadilan nasional. UU No. 24 Tahun 2000 pun tidak menyediakan arahan yang jelas bagaimana efek domestik dari perjanjian internasioanl yang diratifikasi Indonesia. ${ }^{16}$ Perdebatan

12 Ninon Melatyugra, 'Teori Internasionalisme dalam Sistem Hukum Nasional' (2015) 9 Refleksi Hukum 199, 202.

13 Pasal 11 ayat (2) UUD NRI 1945.

14 Pasal 24 ayat (2) UUD NRI 1945.

15 Pasal 1 angka 1 Undang-Undang Republik Indonesia Nomor 48 Tahun 2009 tentang Kekuasaan Kehakiman.

16 Damos Dumoli Agusman, Op.Cit., 358. 
teoretikal seputar monisme-dualisme pun tak dapat dielak sehingga menimbulkan inkonsistensi cara hakim memandang aplikabilitas hukum internasional di pengadilan nasional.

Simon Butt, dalam penelitiannya, menyimpulkan bahwa praktik penggunaan hukum internasional oleh MA dan MK masih berjalan inkonsisten. ${ }^{17}$ Hal tersebut nampak pada praktik MA mengenai kasus Kedutaan Saudi Arabia di Indonesia di tahun 2006. Pada Putusannya, MA menerapkan the 1961 Vienna Convention on Diplomatic Relations yang saat itu sudah diratifikasi namun belum ditransformasi ke dalam hukum nasional. ${ }^{18}$ Praktik MA tersebut menunjukkan bahwa pengadilan menganggap perjanjian internasional tersebut dapat diberlakukan langsung (self-executing treaties). Namun di sisi lain, terdapat juga praktik MA yang bertolakbelakang menyikapi perjanjian internasional. Sebagai contoh, the 1982 United Nations Convention on the Law of the Sea (UNCLOS) merupakan perjanjian internasional yang substansinya mengatur kemaritiman secara umum. Keberlakuan Konvensi tersebut baru didapat setelah Konvensi tersebut ditransformasi ke dalam UU No. 6 Tahun 1996, lebih dari sepuluh tahun setelah ratifikasi Konvensi. Ini menunjukan bahwa treaties tersebut dianggap sebagai non-self executing treaties.

Sampai saat ini, belum ada penjelasan normatif yang dapat menuntaskan polemik praktik inkonsistensi tersebut. Sejalan dengan Simon Butt, Damos Dumoli Agusman juga menyatakan bahwa isu problematik pada status perjanjian internasional dalam hukum nasional di Indonesia merupakan masalah yang belum diselesaikan dan menjadi isu yang tidak begitu berkembang di Indonesia.

\section{Praktik Inggris}

Inggris tidak memiliki konstitusi tertulis yang terkodifikasi serta tidak ada ketentuan peraturan perundangundangan yang membahas spesifik mengenai aplikabilitas hukum internasional dalam sistem hukum nasional. ${ }^{19}$ Namun ketiadaan konstitusi tertulis yang terkodifikasi tersebut tidak lantas menyimpulkan bahwa Inggris tidak memiliki konstitusi. ${ }^{20}$ Sumbersumber Konstitusi Inggris yang muncul semenjak abad ke-17 tersebut telah memungkinkan Parlemen ${ }^{21}$ untuk menentukan ketentuan konstitusional dalam the Bill of Rights of 1689 dan semenjak itu, doktrin legislative

17 Simon Butt, 'The Position of International Law Within The Indonesian Legal System' (2014) 28 Emory International Law Review 1, 6.

$18 \quad$ Ibid. 7.

19 Ibid.

20 Lihat pengertian konstitusi yang dikemukakan oleh Adam Tomkins, "notwithstanding its allegedly unwritten nature, much (indeed, nearly all) of the [English] constitution is written, somewhere" menunjukkan bahwa konstitusi Inggris tersebar ke sejumlah sumber seperti The Magna Carta, the Bill of Rights of 1689, the Parliament Acts of 1911 and 1949, the Human Rights Act of 1998. Titon Slamet Kurnia, Konstitusi HAM: Undang-Undang Dasar Negara Republik Indonesia Tahun 1945 \& Mahkamah Konstitusi Republik Indonesia (Pusat Pelajar 2014) 11.

21 Yang dimaksud Parlemen meliputi House of Commons, House of Lords, dan the Queen (sebagai bagian integral dari Parlemen). 
supremacy of Parliament menjadi doktrin fundamental yang menyatakan hanya Parlemen yang dapat membuat undang-undang ${ }^{22}$ (Parliament Act $^{23}$ ).

Secara umum, pembuatan perjanjian internasional di Inggris memiliki cakupan proses negosiasi, penandatanganan, dan ratifikasi oleh the Royal Prerogative (Pemerintah). ${ }^{24}$ Pemerintah memiliki kewenangan luas untuk menginisiasi pembentukan perjanjian internasional baik yang mengikat ataupun tidak mengikat di hukum internasional, namun apapun status perjanjian tersebut, ketika berbicara mengenai keberlakuan (legal force) perjanjian internasional dalam wilayah domestik Inggris tetap tidak terlepas dari persyaratan transformasi di sistem hukum nasional Inggris. ${ }^{25}$

Melalui the Constitutional Reform and Governance Act 2010, Parlemen memiliki kewenangan untuk mencegah Pemerintah meratifikasi perjanjian internasional yang sedang dinegosiasi 26 dengan prosedur naskah perjanjian internasional diserahkan ke Parlemen selama 21 hari untuk memberi kesempatan pada Parlemen apabila terjadi penolakan, sehingga apabila Parlemen menolak maka ratifikasi tidak dapat dilakukan. ${ }^{27}$ Sebaliknya, apabila rancangan perjanjian internasional mendapat persetujuan dari Parlemen, maka perjanjian internasional tersebut menjadi bagian dari hukum nasional melalui transformasi. Sistem yang demikian menjadikan Inggris sebagai negara dualist yang murni dan konsisten dimana keberlakuan perjanjian internasional ditentukan dari lolosnya naskah tersebut di lembaga Parlemen yang mewajibkan adanya proses transformasi ke dalam hukum nasional.

Terdapat beberapa lembaga peradilan di Inggris yakni Senior Courts yang terdiri dari the High Court of Justice (pengadilan untuk kasus perdata), the Crown Courts (pengadilan untuk kasus pidana), dan Court of Appeal (pengadilan banding). Supreme Court of the United Kingdom merupakan pengadilan banding terakhir yang memiliki yurisdiksi di Inggris, Wales ${ }^{28}$, Scotland ${ }^{29}$, dan Irlandia Utara ${ }^{30}$ (Britania Raya).

Pengadilan di Inggris umumnya berperan dalam fungsi interpretasi untuk isu perjanjian internasional. Seperti contoh kasus Fothergill v. Monarch Airlines di tahun 1981, pengadilan memberi interpretasi terhadap makna kata "damage" dalam the Carriage by Air Act 1961 yang merupakan produk transformasi dari

22 John O’Brien, Op.Cit., 114.

23 Richard Gardiner, International Law (Pearson Education Ltd 2003) 142.

24 John O’Brien, Op.Cit., 120.

25 David Haljan, Separating Powers, International Law Before National Court (T.M.C. Asser Press 2013) 98.

26 Perjanjian internasional yang bersifat mengubah common law atau perundang-undang, mengubah hak dari warga negara Inggris, penyerahan wilayah, penampahan kewenangan the Crown, atau memberlakukan kewajiban financial tambahan. Lihat John O’Brien, Op.Cit, 120.

27 Prosedur ini dinamakan "the Ponson by Rule". Dinah Shelton, International Law and Domestic Legal System (Oxford University Press 2011) 622.

28 The Government of Wales Act 2006.

29 The Scotland Act 1998.

30 The Northern Ireland Act 1998. 
Convention for the Unification of Certain Rules Relating to International Carriage by Air (the Warsaw Convention). Proses interpretasi yang dilakukan oleh hakim cenderung mempertimbangkan karakter internasional dari norma a quo dengan menggunakan fakta di Inggris dan Perancis serta konsensus ahli hukum internasional lalu menyimpulkan bahwa makna kata "damage" juga berarti makna "loss". Contoh ini merupakan sikap pengadilan yang nampak sangat bersahabat hanya terhadap perjanjian internasional yang telah ditransformasi.

Bertolak belakang dengan sikap pengadilan di atas, seorang hakim di pengadilan Inggris dalam kasus $\mathrm{R} v$. Secretary of State for the Home Department menolak gagasan yang menyatakan perjanjian internasional yang belum ditransformasi dapat membatasi ruang lingkup kewenangan diskresi eksekutif. ${ }^{31}$ Pendapat pada sisi yang sama juga dinyatakan oleh Lord Templeman dalam kasus Rayner (Mincing Lane) Ltd v. DTI:

"A treaty is a contract between the governments of two or more sovereign states. International law regulates the relations between sovereign states and determines the validity, the interpretation and the enforcement of treaties. A treaty to which Her Majesty's Government is a party does not alter the laws of the United Kingdom. A treaty may be incorporated into and alter the laws of the United Kingdom by means of legislation. Except to the extent that a treaty becomes incorporated into the laws of the United Kingdom by statute, the courts of the United Kingdom have no power to enforce treaty rights and obligations at the behest of a sovereign government or at the behest of a private individual".

Primat transformasi ini semakin diperkuat dengan paradigma pengadilan Inggris bahwa memorandum of understanding (yang notabene sifatnya hanya intergovernmental tanpa ratifikasi) juga tidak memiliki kekuatan mengikat. ${ }^{32}$

Melihat kepada praktik pengadilan Inggris di atas terhadap perjanjian internasional, maka dapat disimpulkan bahwa pengadilan di Inggris menganggap semua bentuk perjanjian internasional bersifat non-self-executing selama perjanjian internasional tersebut belum ditransformasi ke dalam hukum nasional Inggris.

\section{Praktik Afrika Selatan}

Constitution of the Republic of South Africa dapat menjadi model Konstitusi yang paling ideal dalam menjelaskan posisi hukum internasional dalam sistem hukum nasional. Konstitusi Afrika Selatan memuat otorisasi konstitusional yang langsung merujuk pada hukum internasional dalam isu-isu tertentu sehingga menjernihkan problematik perlakuan negara terhadap hukum internasional dalam wilayah domestik.

$$
\text { Berdasarkan Article 231-233 }
$$
Konstitusi Afrika Selatan, kewenangan untuk membuat perjanjian internasional berada di lembaga the National Executive. Untuk mendapatkan daya keberlakuan ke

\footnotetext{
31 Dalam argumennya, Pemerintah menggunakan dasar Protocol 7 of the European Convention of Human Rights dimana negara Inggris tidak menjadi negara pihak.

32 Lihat pada kasus Brown v. Rwanda di tahun 2009.
} 
dalam wilayah domestik, perjanjian internasional tersebut harus mendapat persetujuan dari the National Assembly dan the National Council of Provinces kemudian ditransformasi ke dalam legislasi nasional. Dari sisi ini, nampak bahwa Afrika Selatan memiliki sifat dualis yang sama dengan Inggris. Namun yang perlu digarisbawahi permintaan transformasi tersebut tidak berlaku apabila persyaratan a priori atau notifikasi terpenuhi. Article 231 (4) menunjukkan ketentuan yang bersifat self-executing dalam suatu perjanjian internasional yang telah disetujui sebelumnya oleh Parlemen serta sesuai dengan Konstitusi dapat langsung berlaku. Persetujuan yang dimaksud terjadi sebelum perjanjian internasional tersebut diratifikasi (a priori). Transformasi juga tidak diperlukan apabila perjanjian internasional tersebut bersifat teknis, administratif, serta tidak membutuhkan ratifikasi atau aksesi. Untuk substansi perjanjian internasional yang demikian, sesuai dengan Article 231 (3), maka hanya diperlukan pemberitahuan terhadap the Assembly dan the Council dalam waktu tertentu (rata-rata dalam 3 bulan).

Kaitannya dengan sistem yudisial, Article 233 dari Konstitusi menyebutkan ketika pengadilan menginterpretasi legislasi apapun, maka ia harus memilih interpretasi yang sesuai dengan hukum internasional ketimbang yang tidak konsisten dengan hukum internasional. Pada isu yang spesifik yakni mengenai interpretasi terhadap hak asasi manusia, Article 39 mengotorisasi pengadilan untuk menggunakan pertimbangan hukum internasional dan hukum asing.
Article 166 dari Konstitusi Afrika Selatan meliputi lembaga the Constitutional Court, the Supreme Court of Appeal, the High Courts, the Magistrate's Courts, dan pengadilan lain yang dibentuk dan diakui oleh Act of Parliament. The Constitutional Court merupakan pengadilan tertinggi untuk isu interpretasi, perlindungan, dan pelaksanaan Konstitusi, sedangkan the Supreme Court of Appeal merupakan pengadilan tertinggi untuk banding melawan putusan dari High Court.

Berdasarkan otorisasi konstitusional yang langsung memberi mandat pada pengadilan nasional Afrika Selatan untuk menggunakan hukum internasional, nampaknya hal tersebut memecahkan persoalan mengenai isu konsistensi perlakuan negara terhadap hukum internasional di forum pengadilan nasional baik di ruang lingkup the Constitutional Court maupun the Supreme Court of Appeal. Pada level interpretasi, pengadilan nasional secara konsisten menggunakan hukum internasional sebagai pedoman dalam interpretasi hak asasi manusia sebagai implikasi dari Article 39 (1) Konstitusi Afrika Selatan.

The Constitutional Court merupakan lembaga yudisial pionir yang menghubungkan Konstitusi dengan hukum internasional dalam hal hak asasi manusia. Beberapa rekam jejam yang menonjol adalah ketika hakim menganggap legislasi nasional the Promotion of Equality and Prevention of Unfair Discrimination Act 4 of 2000 harus diintepretasi dalam konteks hukum internasional, maupun the Refugee Act of 1998 yang harus 
diintepretasi dalam konteks The 1951 Refugees Convention dan Universal Declaration of Human Rights. ${ }^{33}$ Praktik hakim dalam the Constitutional Court tersebut menegaskan bahwa perjanjian internasional di atas memiliki daya keberlakuan langsung di pengadilan nasional melalui metode penafsiran. Praktik tersebut konstitusional karena mendapat otoritas langsung dari Article 39 Konstitusi.

Contoh yang ekstrim ditunjukkan melalui kasus Progress Office Machines ${ }^{34}$ dimana the Supreme Court of Appeal menguji legislasi nasional berdasarkan perjanjian internasional yang belum ditransformasi. Meskipun Afrika Selatan telah meratifikasi the World Trade Organization Agreement on the Implementation of Article VI of the General Agreement on Tariffs and Trade namun perjanjian tersebut belum ditransformasi ke dalam hukum nasional, pengadilan tetap dapat menggunakan perjanjian internasional tersebut sebagai alat interpretasi untuk menguji the International Trade Administration Act 2002 berdasarkan perintah Konstitusi (Article 233). Contoh ini membulatkan suatu kesimpulan bahwa perjanjian internasional dapat berlaku langsung di forum pengadilan nasional, dengan kata lain, "treaties are self-executing before the municipal courts".

\section{Preskripsi untuk Aplikabilitas Perjanjian Internasional di Depan Pengadilan Indonesia}

Natalie Pierce, delegasi New Zealand dalam pertemuan ke-27 International Law Commission's Annual Report, mengatakan bahwa konstitusi suatu negara memiliki peran penting untuk melegitimasi the provisional application of treaties supaya tidak terjadi inkonsistensi pelaksanaan kewajiban internasional dan hukum domestik dalam praktiknya. ${ }^{35}$ Namun manakala konstitusi tidak berbicara bagaimana seharusnya hukum internasional diperlakukan dalam ruang domestik, maka itu menjadi masalah yang harus diselesaikan oleh negara tersebut.

Isu persinggungan hukum internasional dan hukum nasional nampak masif di forum pengadilan nasional Indonesia. ${ }^{36}$ UUD NRI 1945 mengandung gap karena tidak memberikan preskripsi eksplisis posisi hukum internasional di wilayah nasional. Namun jika melihat pada arti konstitusi secara luas yang terdeskripsi dalam praktik Inggris, Indonesia sebenarnya memiliki tradisi konstitusional yang melegitimasi praktik negara untuk menggunakan hukum internasional termasuk di dalamnya perjanjian internasional. Tradisi konstitusional tersebut tergambarkan dari original intention dari pendiri bangsa Indonesia melalui

33 David Sloss, The Role of Domestic Court in Treaty Enforcement (Cambridge University Press 2009$) 463$. Dinah Shelton, Op.Cit., 587.

United Nations, 'As Consideration of International Law Commission Report Concludes, Legal Committee Debates Constitutional Challenges Arising from Treaties' Provisional Application' (2014) <http://www.un.org/press/en/2014/gal3492.doc.htm> diakses 28 Agustus 2018.

36 Isu ini bahkan dibahas secara spesifik oleh Simon Butt, Op.Cit., terutama inkonsistensi praktik pengadilan nasional Indonesia dalam menerapkan hukum internasional, khususnya perjanjian internasional. 
Pembukaan UUD NRI 1945, makna di balik Pasal 11 UUD NRI 1945, ButirButir Pasal HAM dalam UUD NRI 1945, dan pidato Pancasila. ${ }^{37}$

Preskripsi yang ditawarkan di sini bersifat teknis dan singkat tentang bagaimana hakim seharusnya memperlakukan perjanjian internasional dalam forum pengadilan nasional. Sebelum sampai ke sana, asasnya adalah perjanjian internasional di mana Indonesia sudah memberikan consent to be bound adalah hukum sama halnya dengan produk hukum nasional lainnya seperti undang-undang. Asas ini perlu ditekankan karena asas ini merupakan implikasi dari asas hukum internasional yang fundamental, sekaligus universal, yaitu itikad baik atau pacta sunt servanda. ${ }^{38}$ Bertolak dari asas ini maka selanjutnya dikemukakan preskripsi teknis untuk hakim-hakim pengadilan nasional dalam menghadapi isu penerapan perjanjian internasional.

Pertama, hakim perlu menguasai pemahaman terhadap isu perjanjian internasional sehingga ia dapat menghasilkan ratio decidendi yang tepat dalam proses judgment. Kedua, pemahaman terhadap bentuk perjanjian internasional perlu dipertajam sehingga mampu mengidentifikasi perjanjian internasional yang bersifat selfexecuting maupun non self-executing treaties sehingga dapat menentukan akibat hukum (keberlakuan) dari perjanjian internasional yang bermacam-macam jenisnya tersebut.

Tulisan ini juga ingin memberi preskripsi mengenai pertimbangan apa yang sebaiknya digunakan untuk mengkategorikan sebuah perjanjian internasional bersifat non-self-executing yang juga melihat dari perbandingan ketiga negara di atas. Apabila terdapat ketentuan yang berhubungan dengan pemidanaan atau beban keuangan (masih dalam kerangka konstitusional Pasal 11 ayat (2) UUD NRI 1945) maka ketentuan tersebut diperlukan transformasi. Dengan demikian hakim harus benar-benar dapat membedakan karakter dari self-executing dan non-selfexecuting.

\section{PENUTUP}

Keseluruhan pembahasan dalam tulisan ini mendeskripsikan isu ketentuan konstitusional mengenai hukum internasional dan aplikabilitas perjanjian internasional di pengadilan nasional dengan melihat praktik tiga negara. Di Indonesia, ketentuan konstitusional mengenai posisi hukum internasional di hukum nasional masih nampak kabur dikarenakan kekosongan norma eksplisit yang menjelaskannya. Hal tersebut menciptakan keberagaman dan inkonsistensi praktik pengadilan nasional dalam menyikapi perjanjian internasional. Di Inggris, doktrin legislative supremacy of Parliament memberi pengaruh besar dalam

37 Ninon Melatyugra, 'Menggali Tradisi Konstitusional Negara Indonesia Melalui Teori Internasionalisme' dalam Mosaik Pemikiran Hukum: Kumpulan Tulisan dalam Rangka Dies Natalis Fakultas Hukum UKSW Ke-57 (Fakultas Hukum UKSW 2016) 81-85.

38 Mark E. Villiger, Commentary on the 1969 Vienna Convention on the Law of Treaties (Martinus Nijhoff Publishers 2009) 361-368. 
memposisikan hukum internasional di wilayah domestik yang menuntut adanya proses transformasi untuk memiliki daya keberlakuan. Praktik pengadilan nasional di Inggris nampak konsisten dengan doktrin tersebut sehingga setiap perjanjian internasional dianggap non-self-executing. Sedangkan di Afrika Selatan, Konstitusi negara tersebut memberi pedoman yang jelas dalam hal hukum internasional serta didukung oleh praktik pengadilan yang berjalan selaras. Hal tersebut menyimpulkan bahwa perjanjian internasional yang sesuai dengan Konstitusi Afrika Selatan dianggap legislative supremacy of Parliament.

Pada akhirnya tulisan ini memberi saran atau preskripsi bagi Indonesia (khususnya pengadilan nasional) guna meningkatkan sikap friendly attitudenya terhadap hukum internasional dengan cara memperlakukan perjanjian internasional sebagai self-executing treaties untuk norma-norma tertentu yang sejalan dengan UUD NRI 1945. Perlakuan tersebut juga harus disertai pemahaman restrictive yang sesuai dalam kerangka Pasal 11 ayat (2) UUD NRI 1945, bahwa juga terdapat pengecualian terhadap ketentuanketentuan tertentu seperti tentang pemidanaan ataupun keuangan yang tetap harus mengalami proses transformasi. Dengan demikian preskripsi ini diharapkan dapat menjadi pedoman yang memiliki jawaban praktis atas keberagaman dan inkonsistensi praktik pengadilan nasional yang terjadi selama ini.

\section{DAFTAR BACAAN}

\section{Buku}

Agusman, Damos Dumoli, Treaties Under Indonesian Law: A Comparative Study (Remaja Rosdakarya 2014).

Aust, Anthony, Handbook of International Law (Cambridge University Press 2010).

Cali, Basak, The Authority of International Law: Obedience, Respect, and Rebuttal (Oxford University Press 2015).

Dixon, Martin, Textbook on International Law (Blackstone Press Limited 1993).

Gardiner, Richard, International Law (Pearson Education Ltd 2003). Kurnia, Titon Slamet, Konstitusi HAM: Undang-Undang Dasar Negara Republik Indonesia Tahun 1945 \& Mahkamah Konstitusi Republik Indonesia (Pusat Pelajar 2014).

Haljan, David, Separating Powers, International Law Before National Court (T.M.C. Asser Press 2013).

Kurnia, Titon Slamet, Konstitusi HAM: Undang-Undang Dasar Negara Republik Indonesia Tahun 1945 \& Mahkamah Konstitusi Republik Indonesia (Pusat Pelajar 2014).

Lauterpacht, Hersch, International Law: Collected Papers (Cambridge University Press 1970).

Shaw, Malcolm N., International Law: Sixth Edition (Cambridge University Press 2008). 
O’Brien, John, International Law (Cavendish Publishing Ltd London 2001).

Shelton, Dinah, International Law and Domestic Legal System (Oxford University Press 2011).

Sloss, David, The Role of Domestic Court in Treaty Enforcement (Cambridge University Press 2009).

Villiger, Mark E., Commentary on the 1969 Vienna Convention on the Law of Treaties (Martinus Nijhoff Publishers 2009).

\section{Artikel Jurnal}

Butt, Simon, 'The Position of International Law Within The Indonesian Legal System' (2014) 28 Emory International Law Review 1.

Melatyugra, Ninon, Teori Internasionalisme dalam Sistem Hukum Nasional' (2015) 9 Refleksi Hukum 199.

Melatyugra, Ninon, 'Mendorong Sikap Lebih Bersahabat terhadap Hukum Internasional: Penerapan Hukum Internasional oleh Pengadilan Indonesia' (2016) 1 Refleksi Hukum 45.

Melatyugra, Ninon, 'Menggali Tradisi Konstitusional Negara Indonesia Melalui Teori Internasionalisme' dalam Mosaik Pemikiran Hukum: Kumpulan Tulisan dalam Rangka Dies Natalis Fakultas Hukum UKSW $\mathrm{Ke}-57$ (Fakultas Hukum UKSW 2016).

\section{Internet}

United Nations, 'As Consideration of International Law Commission Report Concludes, Legal Committee Debates Constitutional Challenges Arising from Treaties' Provisional Application' (2014) <http://www.un.org/press/en/201 4/gal3492.doc.htm> diakses 28 Agustus 2018.

\section{Peraturan Perundang-Undangan}

The 1951 Refugees Convention.

The 1961 Carriage by Air Act.

The 1961 Vienna Convention on Diplomatic Relations.

The 1982 United Nations Convention on the Law of the Sea.

The 1689 Bill of Rights.

The 1998 Northern Ireland Act.

The 1998 Scotland Act.

The 2000 Promotion of Equality and Prevention of Unfair Discrimination Act 4.

The 2006 Government of Wales Act.

The 2010 Constitutional Reform and Governance Act.

The European Convention of Human Rights.

The Constitution of the Republic of South Africa.

The World Trade Organization Agreement on the Implementation of Article VI of the General Agreement on Tariffs and Trade.

Undang-Undang Dasar Negara Republik Indonesia Tahun 1945. 
Undang-Undang Republik Indonesia Nomor 24 Tahun 2000 tentang Perjanjian Internasional.

Undang-Undang Republik Indonesia Nomor 48 Tahun 2009 tentang Kekuasaan Kehakiman.

Universal Declaration of Human Rights. 
